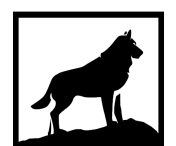

Michigan Technological

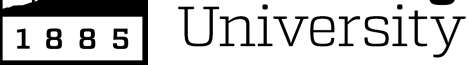

Michigan Technological University Digital Commons @ Michigan Tech

\title{
ARE THE EFFECTS OF ECOSYSTEM NITROGEN SATURATION, INDUCED BY CHRONIC SIMULATED N DEPOSITION, RAPIDLY REVERSIBLE?
}

Jeffrey M. Selan

Michigan Technological University, jmselan@mtu.edu

Copyright 2019 Jeffrey M. Selan

Recommended Citation

Selan, Jeffrey M., "ARE THE EFFECTS OF ECOSYSTEM NITROGEN SATURATION, INDUCED BY CHRONIC SIMULATED N DEPOSITION, RAPIDLY REVERSIBLE?", Open Access Master's Report, Michigan

Technological University, 2019.

https://doi.org/10.37099/mtu.dc.etdr/884 


\title{
ARE THE EFFECTS OF ECOSYSTEM NITROGEN SATURATION, INDUCED BY CHRONIC SIMULATED N DEPOSITION, RAPIDLY REVERSIBLE?
}

\author{
By \\ Jeffrey M. Selan
}

\begin{abstract}
A REPORT
Submitted in partial fulfillment of the requirements for the degree of MASTER OF SCIENCE

In Forest Ecology and Management
\end{abstract}

MICHIGAN TECHNOLOGICAL UNVERSITY

2019

(C) 2019 Jeffrey M. Selan 
This report has been approved in partial fulfillment of the requirements for the Degree of MASTER OF SCIENCE in Forest Ecology and Management.

School of Forest Resources and Environmental Science

\author{
Report Advisor: $\quad$ Andrew Burton \\ Committee Member: $\quad$ Tara Bal \\ Committee Member: $\quad$ Evan Kane \\ School Dean: $\quad$ Andrew Storer
}




\section{Dedication page}

This report is dedicated to a life-long mentor and friend,

Dennis M. Braun. His dedicated career and services as a

Pennsylvania Forester inspired my academic pursuits in

Natural Resources. 


\section{Table of Contents}

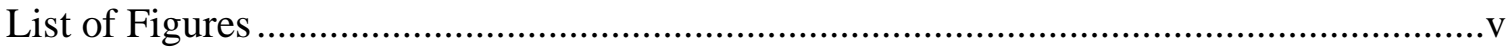

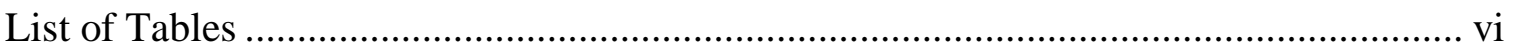

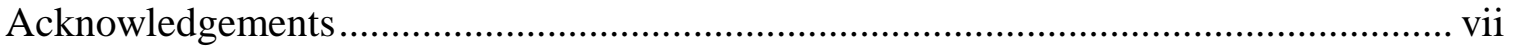

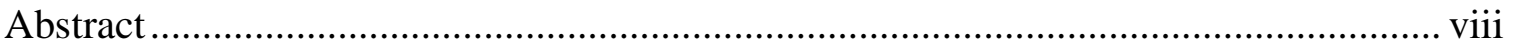

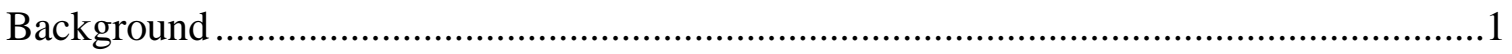

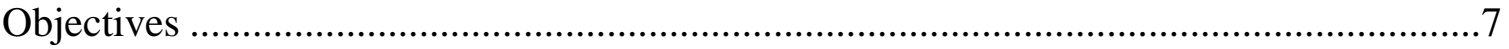

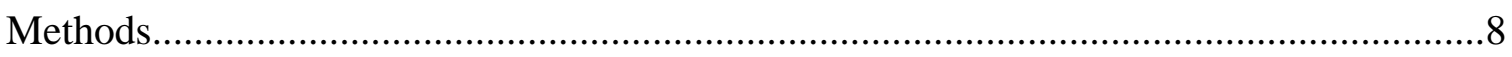

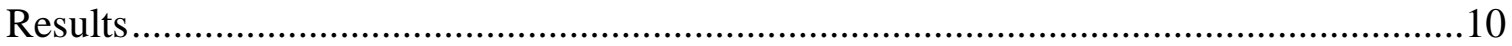

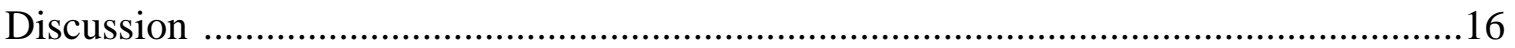

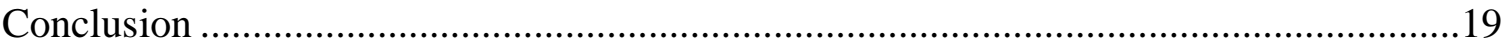

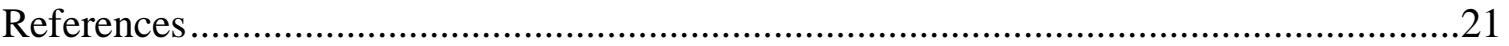




\section{List of Figures}

Figure 1. Chronic experimental $\mathrm{N}$ deposition study sites in Michigan.................................2

Figure 2. Soil solution total dissolved nitrogen (TDN, upper plate) and dissolved organic carbon (DOC, lower plate) from the four $\mathrm{N}$ deposition study sites in Michigan, 2017

Figure 3. Average basal area increments by treatment from 1994 through 2017 in Michigan $\mathrm{N}$ deposition study sites

Figure 4. Nitrogen (upper plate) and C (lower plate) concentrations in Acer saccharum leaf litter from 2018 for the control and former $\mathrm{N}$ deposition treatments at the four study sites in Michigan.

Figure 5. Average Acer saccharum leaf litter N (upper plate) and C (lower plate) concentrations by treatment from 1994 to 2018 at the Michigan study sites

Figure 6. Total dissolved nitrogen (upper plate) and dissolved organic C (lower plate) concentrations in soil solution at Site A, Michigan, by sample date for the first year (2018) after ending the $\mathrm{N}$ deposition treatment

Figure 7. Soil solution dissolved organic C (DOC, upper plate) and total dissolved $\mathrm{N}$ (TDN, lower plate) concentrations for Site A, Michigan, for the control and N deposition treatments from 1994 to 2018 


\section{List of Tables}

Table 1. Summary of selected ecosystem responses to chronic experimental $\mathrm{N}$ deposition in four northern hardwood forests, Michigan, USA............................................3

Table 2. Site characteristics of the four northern hardwood forests in Michigan, USA......9

Table 3. Two factor (site, treatment) analysis of variance of sugar maple foliar litter $\mathrm{N}$ concentration $\left(\mathrm{g} \mathrm{N} \mathrm{kg}^{-1}\right)$ and $\mathrm{C}$ concentration $\left(\mathrm{g} \mathrm{C} \mathrm{kg}^{-1}\right)$ from the four $\mathrm{N}$ deposition study sites in Michigan, 2018 .........................................................11

Table 4. Single factor analysis of variance of the soil solution TDN $\left(\mathrm{mg} \mathrm{N} \mathrm{L}^{-1}\right)$ and DOC (mg C L ${ }^{-1}$ ) from Site A in Michigan, 2018. 16 


\section{Acknowledgements}

I would like to thank my advisor, Andrew Burton, for helping me realize my academic potential as well as his guidance, support, and mentorship throughout my pursuit of a Master's degree. Many thanks to my committee members, Tara Bal and Evan Kane, for their advice, comments and suggestions throughout the entire process. Also, I would like to thank Jennifer Eikenberry for her help processing the samples and for allowing use of the lab space. A special thanks to undergraduate assistant, Ashley Berton, for her assistance

in the lab. Finally, I would like to thank my friends and family for their encouragement and support throughout the research preparation process.

Funding for this project was provided by The Ecosystem Science Center at Michigan Technological University, the USDA McIntire-Stennis Program, and the National Science Foundation, Grant DEB1251529. 


\begin{abstract}
A novel follow-on study examines the recovery of ecosystem processes in 2018, following the cessation of chronic $\mathrm{N}$ deposition additions from 1994 to 2017, to a series of northern hardwood forest stands in Michigan. This recovery study focuses on the response to reduced $\mathrm{N}$ deposition of dissolved organic $\mathrm{C}$ (DOC) and total dissolved $\mathrm{N}$ (TDN) in soil solution and leaf litter $\mathrm{N}$ concentration. The findings suggest that even after $\mathrm{N}$ treatment to the system had stopped, $\mathrm{N}$ saturation was sustained, as soil solution outputs of $\mathrm{N}$ from the system were approximately equal to ambient $\mathrm{N}$ deposition inputs. Leaf litter $\mathrm{N}$ also remained elevated, which could lead to a continuation of many of the other responses associated with elevated $\mathrm{N}$, including elevated DOC leaching. The study sites continue to exhibit effects of $\mathrm{N}$ saturated ecosystems during the first year of recovery, but more time will be needed to fully understand the long-term recovery effects to reduced $\mathrm{N}$ inputs to the ecosystems.
\end{abstract}

Key abbreviations: Nitrogen (N), Carbon (C), Total Dissolved Nitrogen (TDN), Dissolved Organic Nitrogen (DON), Dissolved Organic Carbon (DOC) 


\section{Background}

Research conducted from 1994 to 2017 tested the effects of simulated elevated atmospheric $\mathrm{NO}_{3}{ }^{-}$deposition $\left(3 \mathrm{~g} \mathrm{~N} \mathrm{~m}^{-2} \mathrm{y}^{-1}\right)$ on northern hardwood forests in Michigan (Burton et al. 2004). The sites, spanning a 500-km climatic gradient, extended across the north-south geographic range for sugar maple-dominated (Acer saccharum Marsh.), northern hardwood forests in the Great Lakes (Braun 1950) (Figure 1). In late 2017, the experimental $\mathrm{N}$ additions were stopped. This change for the sites effectively represented the recent declining trend of $\mathrm{N}$ deposition in the northeastern USA and western portions of Europe as a result of stricter emission controls (Du et al. 2014, Rogora et al. 2016).

Early during the 24-year $\mathrm{N}$ deposition study, all four study sites achieved a state of $\mathrm{N}$ saturation as defined by Aber et al. $(1989,1998)$. A site that is fully saturated with $\mathrm{N}$ has a steady and continuous increase in soil solution leaching losses of $\mathrm{NO}_{3}^{-}$(Aber et al. 1989). At the Michigan study sites increased soil solution losses of dissolved organic C (DOC) and dissolved organic N (DON) also occurred (Pregitzer et al. 2004, Table 1, Figure 2).

In addition, simulated $\mathrm{N}$ deposition incrementally increased annual diameter and height growth of measured trees within the $\mathrm{N}$ deposition treatment (Table 1, Figure 3) (Ibanez et al. 2016). The chronic $\mathrm{N}$ additions also reduced soil respiration (Burton et al. 2004) and litter decay, causing a rapid accumulation of soil organic matter (Pregitzer et al. 2008, Zak et al. 2008, Frey et al. 2014). The reduction in litter decay rates was associated with a large increase in litter $\mathrm{N}$ concentration (Table 1) and changes in decomposer community function with elevated $\mathrm{N}$ availability that led to less complete decomposition of litter inputs 
(Whittinghill et al. 2012). The $\mathrm{N}$ deposition treatment significantly increased total ecosystem C storage over a relatively short time, with greater than $10 \%$ increases in soil organic matter and above-ground net primary productivity (NPP) within the first decade (Pregitzer et al. 2008, Zak et al. 2008) that continued throughout the period of $\mathrm{N}$ addition. More recently, the $\mathrm{N}$ deposition treatment was found to slow the decay rate of coarse woody debris, further contributing to increased ecosystem C storage (Lyons 2012).

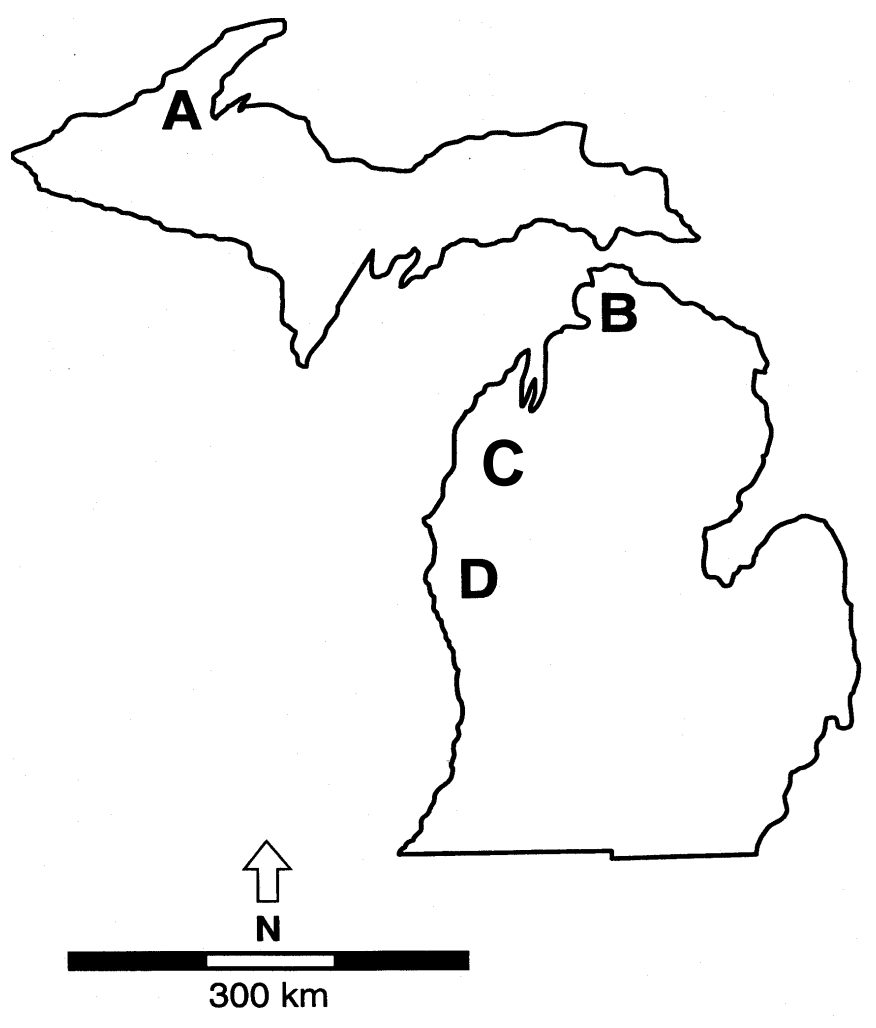

Figure 1. Chronic experimental $\mathrm{N}$ deposition study sites in Michigan (map modified from Burton et al. 2004). 
Table 1. Summary of selected ecosystem responses to chronic experimental $\mathrm{N}$ deposition in four northern hardwood forests in Michigan, USA. Responses with a change indicated were statistically significant $(P<0.05)$. Those with an $*$ had a site by treatment interaction, with greater responses in more northerly sites.

\begin{tabular}{lll}
\hline Measurement & Response & Reference \\
\hline Overstory basal area growth & increase*, 13\% & $\begin{array}{l}\text { Pregitzer et al. 2008; } \\
\text { Ibanez et al. 2016 }\end{array}$ \\
Overstory tree mortality & similar rate & $\begin{array}{l}\text { Pregitzer et al. 2008 } \\
\text { Seedling survival rate }\end{array}$ \\
decrease*, 49\% & $\begin{array}{l}\text { Patterson et al. 2012; } \\
\text { Talhelm et al. 2013 }\end{array}$ \\
Leaf litter N & increase, 19\% & Pregitzer et al. 2008 \\
Soil respiration & decrease, 13\% & Burton et al. 2004 \\
Forest floor \& surface soil C & increase*, 26\% & Pregitzer et al. 2008 \\
Coarse woody debris mass loss & decrease, 37\% & Lyons 2012 \\
Soil solution NO ${ }^{-}$ & increase, 2200\% & Pregitzer et al. 2004 \\
Soil solution DON & increase, 300\% & Pregitzer et al. 2004 \\
Soil solution DOC & increase, 500\% & Pregitzer et al. 2004 \\
Litter mass & no change & Pregitzer et al. 2008 \\
Leaf area index & no change & Pregitzer et al. 2008 \\
Fine and coarse root respiration & no change & Burton et al. 2012 \\
Surface fine root N & no change & Burton et al. 2012 \\
Deep fine root \& coarse root N & increase, 30\% & Burton et al. 2012 \\
Fine and coarse root biomass & no change & Burton et al. 2012 \\
Mycorrhizal hyphal biomass & decrease, 41\% & van Diepen et al. 2010 \\
Photosynthetic rate & no change & Talhelm et al. 2011 \\
\hline
\end{tabular}



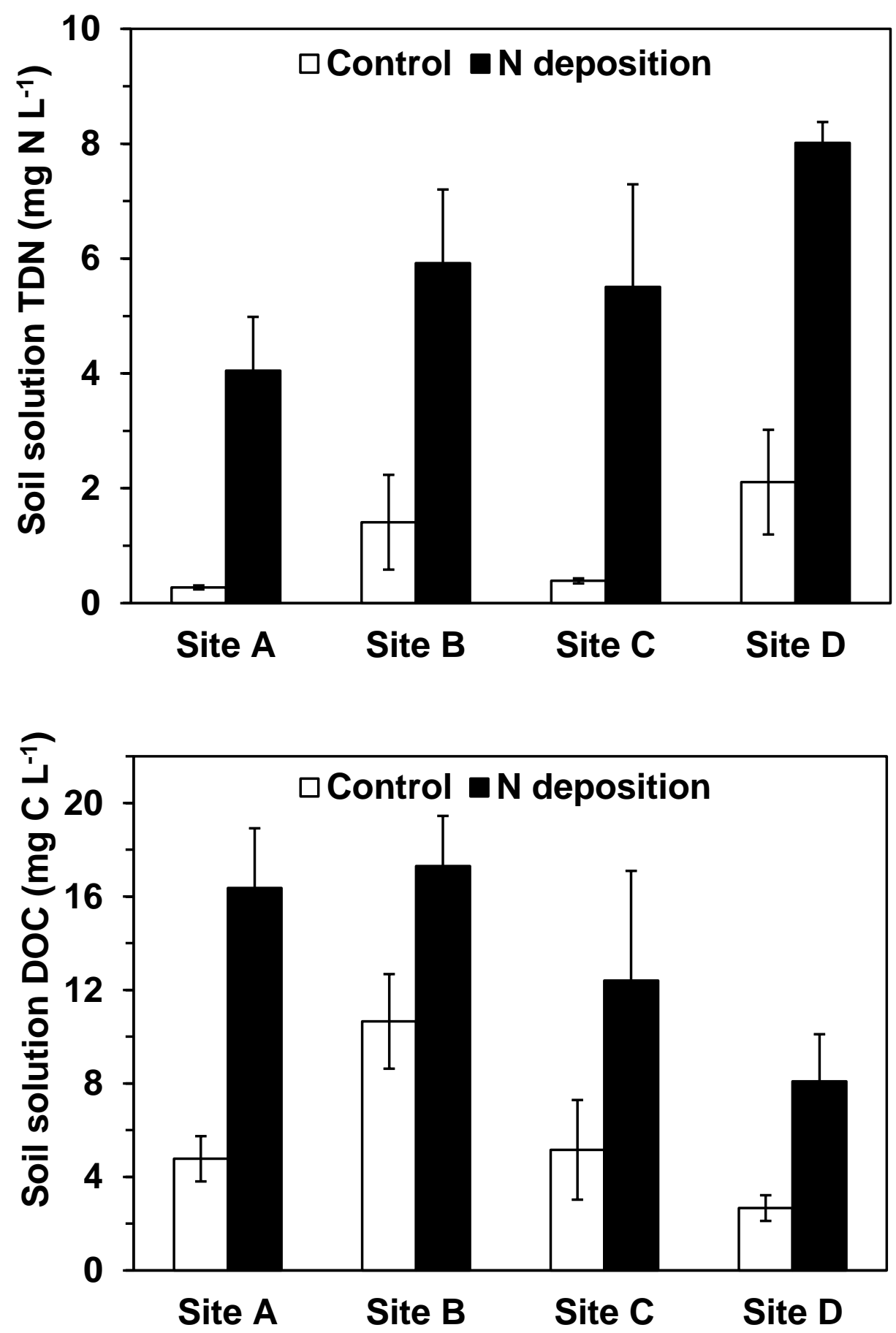

Figure 2. Soil solution total dissolved nitrogen (TDN, upper plate) and dissolved organic carbon (DOC, lower plate) from the four N deposition study sites in Michigan, 2017. Error bars are one standard error of the mean ( $n=3$ plots per site and treatment). 


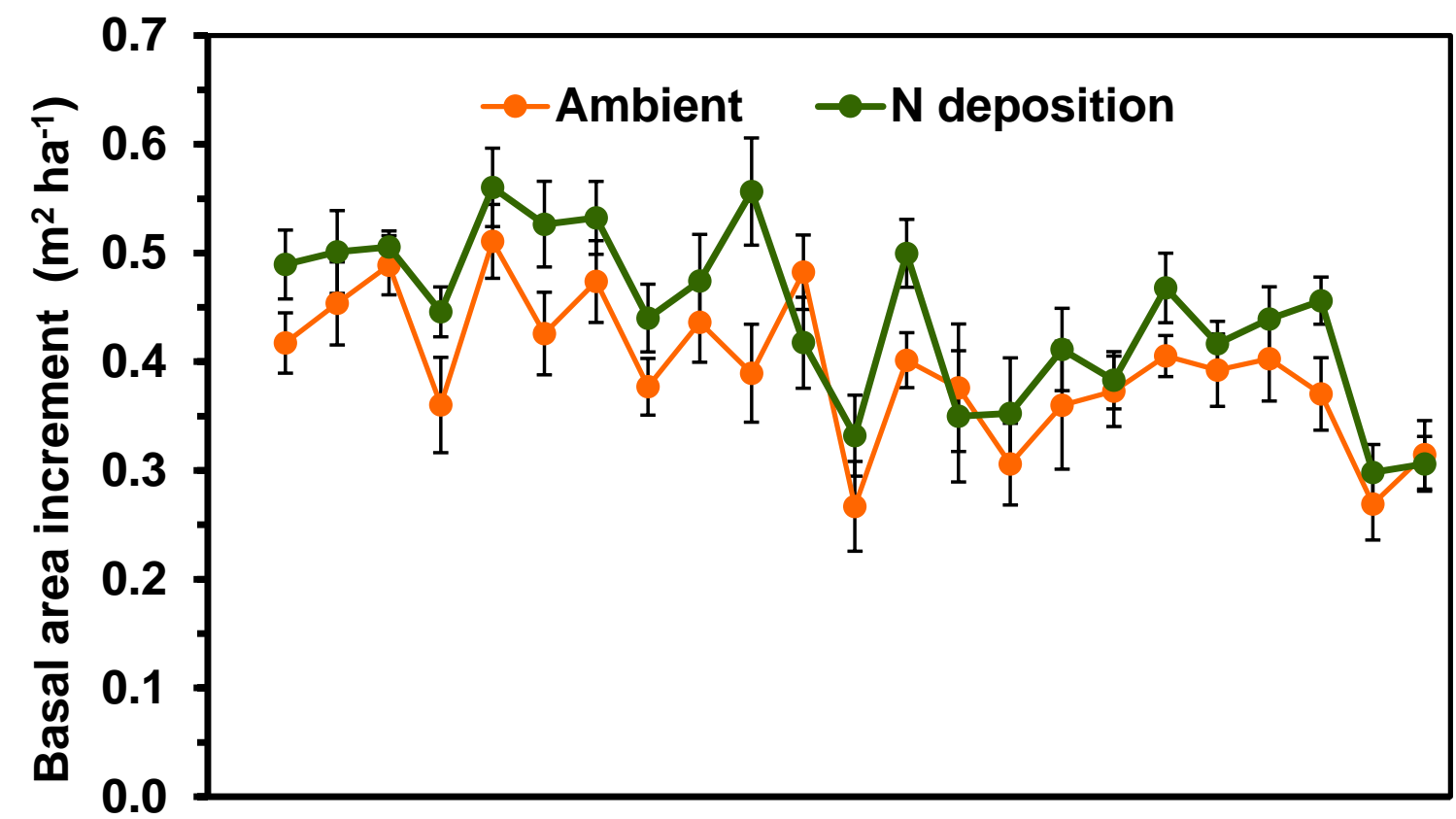

949596979899000102030405060708091011121314151617 Year 2017

Figure 3. Average basal area increments by treatment from 1994 through 2017 in Michigan $\mathrm{N}$ deposition study sites. Basal area increment is significantly higher for the simulated $\mathrm{N}$ deposition treatment, by an average of $12 \%(P<0.05)$ for the 24-year period. Values are means and standard error $(n=12)$ for all plots of a treatment across all four sites.

Since late 2017, the 24-year delivery of $3 \mathrm{~g} \mathrm{NO}_{3}-\mathrm{N} \mathrm{m}^{-2} \mathrm{y}^{-1}$ has no longer been applied to any of the sites, ending one of the largest and longest running, atmospheric $\mathrm{N}$ deposition manipulation experiments in a forest ecosystem. Data and samples collected in 2018, the first year after experimental $\mathrm{N}$ additions ceased, form the initial basis for a follow-up study designed to understand the recovery of an $\mathrm{N}$ saturated ecosystem after $\mathrm{N}$ deposition inputs decrease. The data will help bridge the gap between known impacts of chronic elevated $\mathrm{N}$ inputs and a lack of knowledge regarding how reversible the effects are after $\mathrm{N}$ inputs are decreased. Since elevated $\mathrm{N}$ is directly linked to climate change through its impact on ecosystem C storage and cycling (Magnani et al. 2007, Lu et al. 2016b), an improved 
understanding of the impacts and future dynamics of experimental $\mathrm{N}$ in forest ecosystems can help scientists better predict how forests recover with $\mathrm{N}$ deposition reduction and how this in turn affects ecosystem $\mathrm{C}$ cycling and storage.

Fully determining how an ecosystem recovers after being subjected to high levels of $\mathrm{N}$ will take time, and a precise interpretation may take years to fully conceptualize $\mathrm{N}$ recovery trends. It is not known if ambient $\mathrm{N}$ deposition, which is moderately elevated ( 0.4 to $0.5 \mathrm{~g}$ $\mathrm{N} \mathrm{m}^{-2} \mathrm{y}^{-1}$ ), can effectively maintain the state of $\mathrm{N}$ saturation that was induced by chronic high rates of experimental $\mathrm{N}$ deposition $\left(3 \mathrm{~g} \mathrm{~N} \mathrm{~m}^{-2} \mathrm{y}^{-1}\right.$ above ambient). If this is the case, it is likely that soil solution $\mathrm{N}$ losses will diminish but remain elevated during the first year of $\mathrm{N}$ recovery. In the long term, if the soil solution continues to be elevated over the control at a level approximately equivalent to $\mathrm{N}$ deposition inputs, this would indicate that the sites remain $\mathrm{N}$ saturated.

Another way to determine if the sites continue to have excess $\mathrm{N}$ is by the examining leaf litter N. If it remains elevated, it would indicate the likelihood of excess ecosystem N, which could continue to cause a reduction of microbial decomposition of organic matter and resulting elevated soil carbon storage. In contrast, if the sites become non-N-saturated, the decomposition processes might no longer be inhibited by excess $\mathrm{N}$, which over time could lead to the loss of the additional soil organic matter that had accumulated during the 24 years of chronic $\mathrm{N}$ deposition. More rapid decomposition could return much of extra stored $\mathrm{C}$ to the atmosphere, where it would contribute to rising atmospheric $\mathrm{CO}_{2}$ concentrations and climate change. This study will focus specifically on soil solution $\mathrm{N}$ 
and $\mathrm{C}$ losses and leaf litter $\mathrm{N}$ concentration as potential indicators of continuing ecosystem $\mathrm{N}$ saturation and excess soil $\mathrm{N}$ availability.

\section{Objectives}

Objectives of the analyses of leaf litter and soil solution samples collected in 2018 at the treatment sites were to determine if: 1) the soil solution $\mathrm{N}$ and $\mathrm{C}$ losses remain elevated within the $\mathrm{N}$ saturated system as $\mathrm{N}$ inputs are reduced one year after deposition has ended; and 2) leaf litter $\mathrm{N}$ remains elevated, one year after deposition ended. The initial hypothesis pertaining to the recovery of the $\mathrm{N}$ saturated systems is that ambient rates of $\mathrm{N}$ deposition, which are somewhat elevated due to regional pollutant $\mathrm{N}$ deposition (Lu et al. 2016a), will be enough to keep the sites N saturated, with DOC leaching losses remaining elevated and TDN losses equivalent to ambient $\mathrm{N}$ deposition inputs for the former $\mathrm{N}$ addition treatment. Most ecosystems have a lag for when the effects from the environmental changes occur. It is believed that ecosystem recovery would share a similar lag effect also seen in the initial stages of the $\mathrm{N}$ deposition study where responses developed over several years. Leaf litter N remaining elevated would be evidence that site's $\mathrm{N}$ availability remains elevated. The elevation of $\mathrm{N}$ created by the long-term experimental $\mathrm{N}$ deposition could contribute to continued alteration of microbial community composition and function and reductions in decomposition rates and soil respiration, similar to those that resulted in enhanced soil $\mathrm{C}$ storage buildup during the period of $\mathrm{N}$ additions. This recovery study will begin to assess if a fully $\mathrm{N}$ saturated site will remain saturated under ambient $\mathrm{N}$ deposition inputs or if the system will begin to revert back to natural levels of ecosystem processes seen before $\mathrm{N}$ was deposited artificially onto the study sites. 


\section{Methods}

The recovery study uses four $100+$ year-old northern hardwood forests located in Michigan. Each site is primarily dominated by sugar maple (Acer saccharum Marsh.). The soil characteristics are consistent with sandy, well-drained Spodosol soils (Table 2). The average temperature increases from 4.9 to $7.7{ }^{\circ} \mathrm{C}$ from north (Site A) to south (Site D) across the sites. The mean average precipitation is $873 \mathrm{~mm}$, with site $\mathrm{C}$ having the largest amount at $913 \mathrm{~mm}$ of precipitation.

This study utilized the collection of leaf litter at each site (four sites total) and soil solution from Site A in 2018, the first year after experimental $\mathrm{N}$ additions had ended. There are three $30 \mathrm{~m}$ by $30 \mathrm{~m}$ plots at each site that have served as the control and only received ambient atmospheric $\mathrm{N}$ inputs, while three other plots at each site were subjected to experimental $\mathrm{N}$ inputs of $3 \mathrm{~g} \mathrm{NO}_{3}{ }^{-}-\mathrm{N} \mathrm{m}^{-2} \mathrm{y}^{-1}$, delivered over the growing season in six equal applications $\left(0.5 \mathrm{~g} \mathrm{~N} \mathrm{~m}^{-2} \mathrm{month}^{-1}\right)$, from 1994 to 2017 during the $\mathrm{N}$ deposition study.

Leaf litter was collected monthly during the snow free season using four $0.5 \mathrm{~m}^{2}$ litter traps per plot. In 2018, litter from all dates from one plot per site was composited and sorted by species. Sugar maple was the only leaf species analyzed annually for $\mathrm{N}$ concentrations, as it is the dominant overstory species at all sites (Table 2). The sample of sugar maple leaves composited across sample dates for the year from each plot was ground to a fine powder to produce a uniform sample small enough to be placed inside an Element Analyzer (EA, Model 4010 Elemental Combustion System, Costech Technologies, Inc. Valencia CA, USA) for $\mathrm{C}$ and $\mathrm{N}$ determination. 
Table 2. Site characteristics of the four northern hardwood forests in Michigan, USA.

\begin{tabular}{|c|c|c|c|c|}
\hline Characteristic & Site A & Site B & Site C & Site D \\
\hline Latitude $(\mathrm{N})$ & $46^{\circ} 52^{\prime}$ & $45^{\circ} 33^{\prime}$ & $44^{\circ} 23^{\prime}$ & $43^{\circ} 40^{\prime}$ \\
\hline Longitude (W) & $88^{\circ} 53^{\prime}$ & $84^{\circ} 51^{\prime}$ & $85^{\circ} 50^{\prime}$ & $86^{\circ} 09^{\prime}$ \\
\hline Basal area $\left(\mathrm{m}^{2} \mathrm{ha}^{-1}\right)$ & 35.7 & 33.6 & 33.9 & 37.7 \\
\hline Sugar maple (\% of basal area) & 91 & 86 & 79 & 71 \\
\hline Mean annual precipitation ${ }^{\mathrm{a}}(\mathrm{mm})$ & 879 & 874 & 913 & 824 \\
\hline Growing season precipitation $^{\mathrm{a}}(\mathrm{mm})$ & 401 & 388 & 393 & 379 \\
\hline Mean annual temperature ${ }^{\mathrm{b}}\left({ }^{\circ} \mathrm{C}\right)$ & 4.9 & 6.2 & 7.0 & 7.7 \\
\hline Growing season temperature ${ }^{\mathrm{b}}\left({ }^{\mathrm{o}} \mathrm{C}\right)$ & 15.0 & 16.0 & 16.2 & 16.8 \\
\hline Growing season length ${ }^{\mathrm{c}}$ (days) & 134 & 153 & 160 & 163 \\
\hline Overstory age (2018) & 111 & 105 & 106 & 110 \\
\hline Wet + dry total $\mathrm{N}$ deposition $\left(\mathrm{g} \mathrm{N} \mathrm{m}^{-2} \mathrm{y}^{-1}\right)^{\mathrm{d}}$ & 0.45 & 0.65 & 0.88 & 0.95 \\
\hline
\end{tabular}

$\overline{{ }^{a}}$ Mean annual and growing season (May - September) precipitation was recorded using weighing rain gages (Model 5-780, Belfort Instrument Co., Baltimore, MD) located in open areas within $5 \mathrm{~km}$ of each site.

${ }^{b}$ Mean annual and growing season (May - September) temperature was recorded on site at $2 \mathrm{~m}$ using thermistors which were read every 30 minutes throughout the year, with averages recorded every 3 h using data loggers (EasyLogger Models 824 and 925, Data Loggers, Inc., Logan UT).

${ }^{\mathrm{c}}$ Growing season length, for the years 2007 to 2016, was determined annually by project personnel, based on visual estimates of $>50 \%$ leaf expansion in the spring and $<75 \%$ of foliage remaining in the fall.

${ }^{\mathrm{d}}$ Estimated from CASTNET (Clean Air Status and Trends Network) total N deposition maps for the period 2015-2017 (https://www3.epa.gov/castnet/totaldep.html, accessed May 28, 2019). 
The soil solution was collected approximately biweekly in the spring and fall of 2018, when soil water recharge was occurring. Soil solution samples were obtained using four tension lysimeters installed in each plot at a depth of $75 \mathrm{~cm}$ (below the primary rooting zone, Pregitzer et al. 2004). These were composited by plot within each sample date, filtered $(0.45 \mu)$ and stored refrigerated until analysis. These samples were then analyzed for DOC and TDN concentrations using Model TOC-V Combustion Analyzer with TNM1 Total Nitrogen Option, Shimadzu Scientific Instruments, Inc., Columbia, MD, USA (Matejovic, 1993). In 2018, soil solution was collected only from Site A.

Nitrogen and carbon concentrations for sugar maple leaf litter in 2018 were assessed using a two-factor (study site $\mathrm{x}$ treatment) analysis of variance. Site A was the only the site with samples collected for soil solution TDN and DOC. Treatment effects for TDN and DOC were statistically evaluated using a single factor analysis of variance.

\section{Results}

Leaf litter $\mathrm{N}$ concentrations remained elevated in the former $\mathrm{N}$ deposition treatment when compared to the control (Table 3, Figure 4), though the increase in $\mathrm{N}$ concentration over the control in 2018 was less than that during the treatment period of the deposition study (Figure 5). The 2018 data suggest litter $\mathrm{N}$ concentration is $10 \%$ greater in the former $\mathrm{N}$ deposition treatment in 2018, whereas during the experimental deposition period, average concentrations (last ten years of data, 2008 to 2017) were $21 \%$ greater than the control (Figure 4 and 5). There also were significant differences among sites (Table 3). For leaf litter $\mathrm{C}$, it is important to note that levels of $\mathrm{C}$ are significantly elevated when compared to 
control, one year after deposition has stopped (Table 3, Figure 4 and 5). This can be seen by using the same process as the $\mathrm{N}$ concentration and averaging the last ten years of data at approximately $1.1 \%$ and comparing with 2018 data at approximately $1.7 \%$.

The recovery of the former $\mathrm{N}$ deposition treatment is also minimal for soil solution and only reflects the ecosystem $\mathrm{N}$ input change after experimental $\mathrm{N}$ deposition was stopped. The TDN and DOC levels in soil solution have remained elevated when compared to the control (Table 4, Figure 6). The increase in TDN is lower than during the experimental $\mathrm{N}$ addition period (Figure 7). Soil solution DOC remained elevated in 2018 at levels of approximately $17 \mathrm{mg} \mathrm{C} \mathrm{L}^{-1}$ (Figure 6), which was very similar to those occurring during the experimental $\mathrm{N}$ addition period (Figure 7).

Table 3. Two factor (site, treatment) analysis of variance of sugar maple foliar litter $\mathrm{N}$ concentration $\left(\mathrm{g} \mathrm{N} \mathrm{kg}^{-1}\right)$ and $\mathrm{C}$ concentration $\left(\mathrm{g} \mathrm{C} \mathrm{kg}^{-1}\right)$ from the four $\mathrm{N}$ deposition study sites in Michigan, 2018.

\begin{tabular}{|c|c|c|c|c|c|c|}
\hline Analyte & $\begin{array}{l}\text { Source of } \\
\text { Variation } \\
\end{array}$ & SS & df & MS & $\mathbf{F}$ & $P$-value \\
\hline \multirow[t]{5}{*}{ Litter N } & Site & 28.72 & 3 & 9.57 & 16.80 & $<0.001$ \\
\hline & Treatment & 4.64 & 1 & 4.64 & 8.14 & 0.012 \\
\hline & Site $\mathrm{x}$ treatment & 3.09 & 3 & 1.03 & 1.81 & 0.186 \\
\hline & Error & 9.12 & 16 & 0.57 & & \\
\hline & Total & 45.58 & 23 & & & \\
\hline \multirow[t]{5}{*}{ Litter C } & Site & 282.9 & 3 & 94.3 & 2.98 & 0.062 \\
\hline & Treatment & 345.7 & 1 & 345.7 & 10.94 & 0.004 \\
\hline & Site $\mathrm{x}$ treatment & 0.9 & 3 & 0.3 & 0.01 & 0.999 \\
\hline & Error & 505.8 & 16 & 31.6 & & \\
\hline & Total & 1135.3 & 23 & & & \\
\hline
\end{tabular}



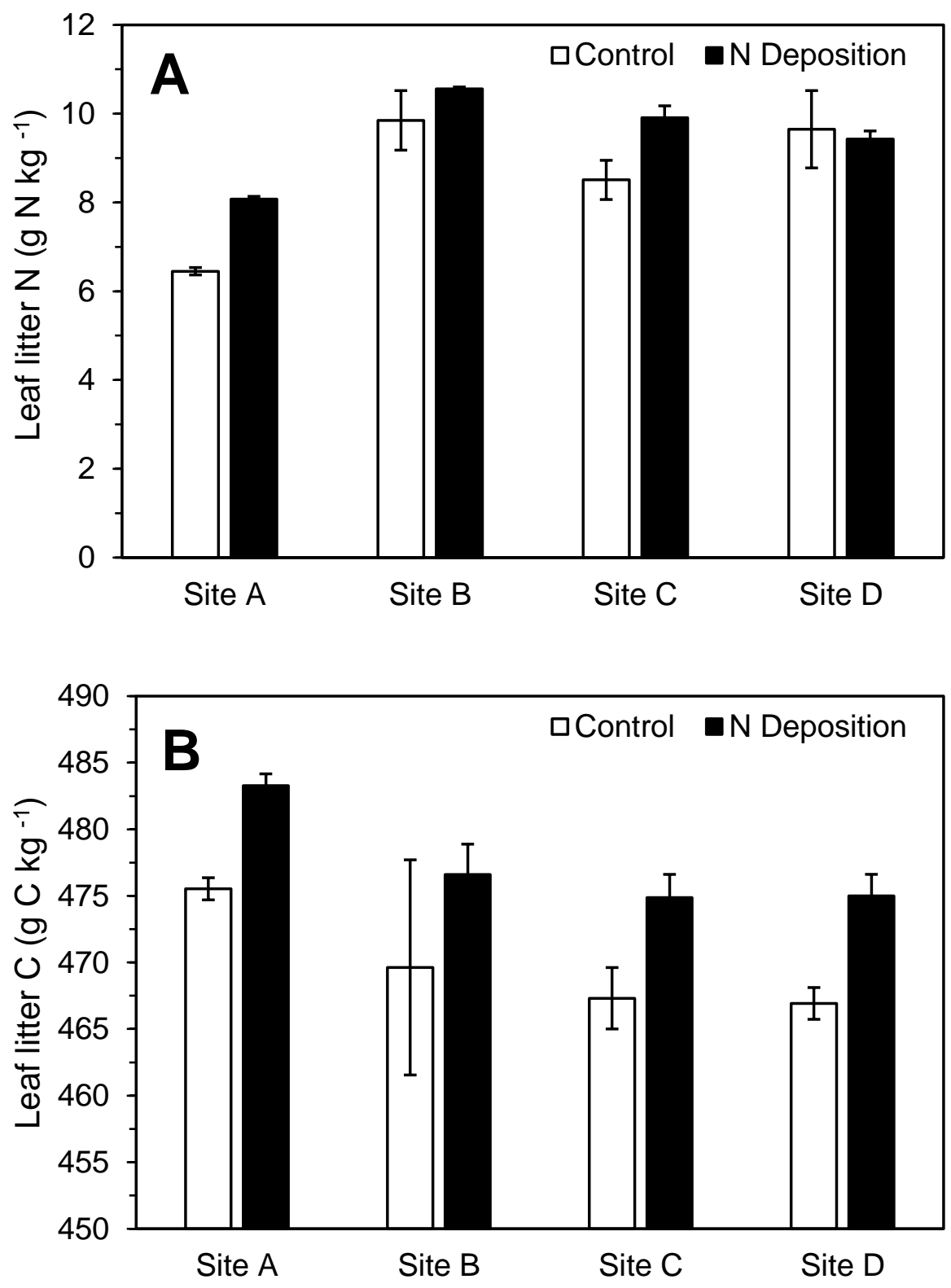

Figure 4. Nitrogen (upper plate, A) and C (lower plate, B) concentrations in Acer saccharum leaf litter from 2018 for the control and former $\mathrm{N}$ deposition treatments at the four study sites in Michigan. Error bars are one standard error of the mean $(n=3$ plots per site and treatment). 

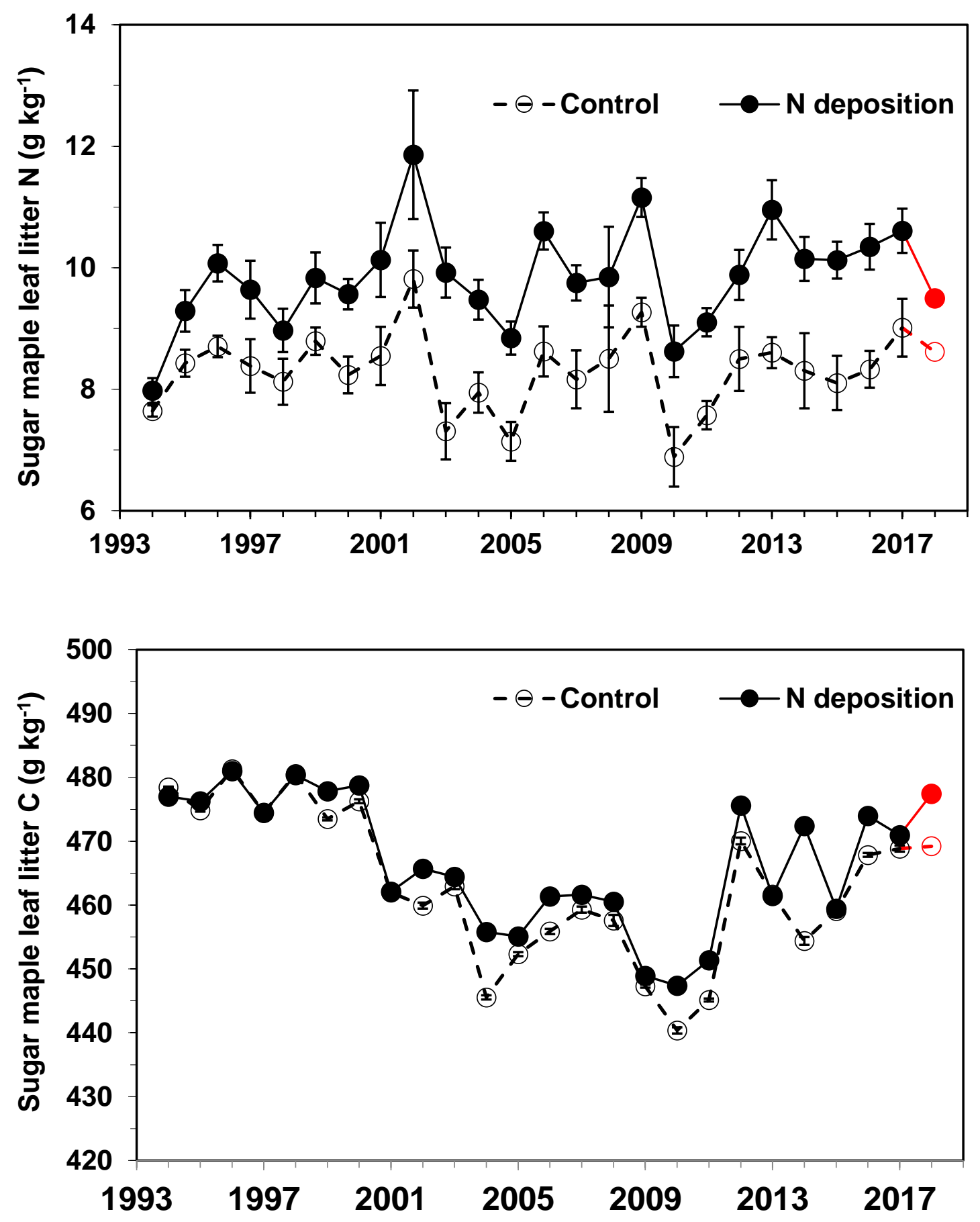

Figure 5. Average Acer saccharum leaf litter N (upper plate) and C (lower plate) concentrations by treatment from 1994 to 2018 at the Michigan study sites. The 2018 values (red) are the first year of data in the recovery study. All years prior to 2018, N was being applied to the sites. 

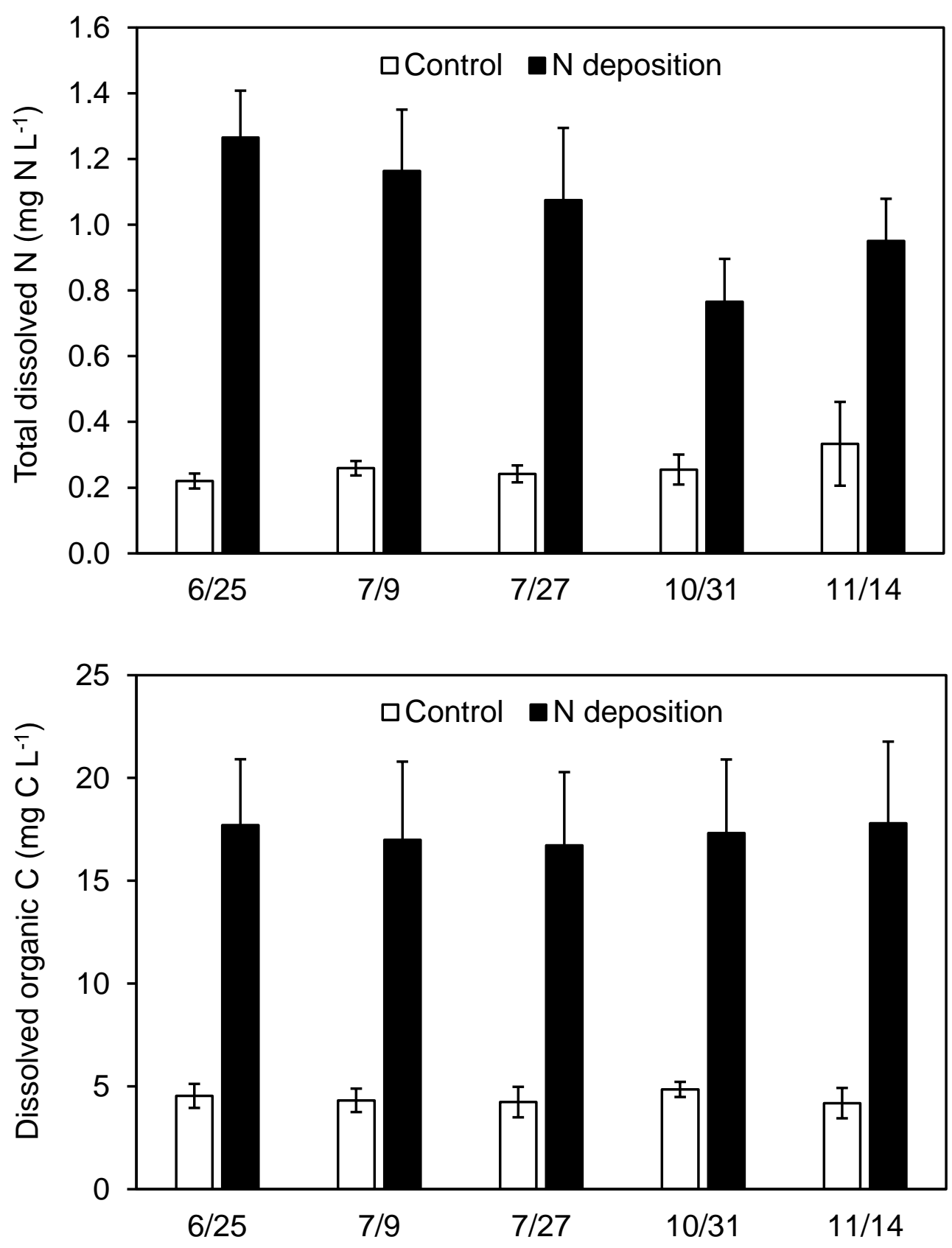

Figure 6. Total dissolved nitrogen (upper plate) and dissolved organic C (lower plate) concentrations in soil solution at Site A, Michigan, by sample date for the first year (2018) after ending the $\mathrm{N}$ deposition treatment. Error bars are one standard error of the mean for each date ( $\mathrm{n}=3$ plots per treatment). 

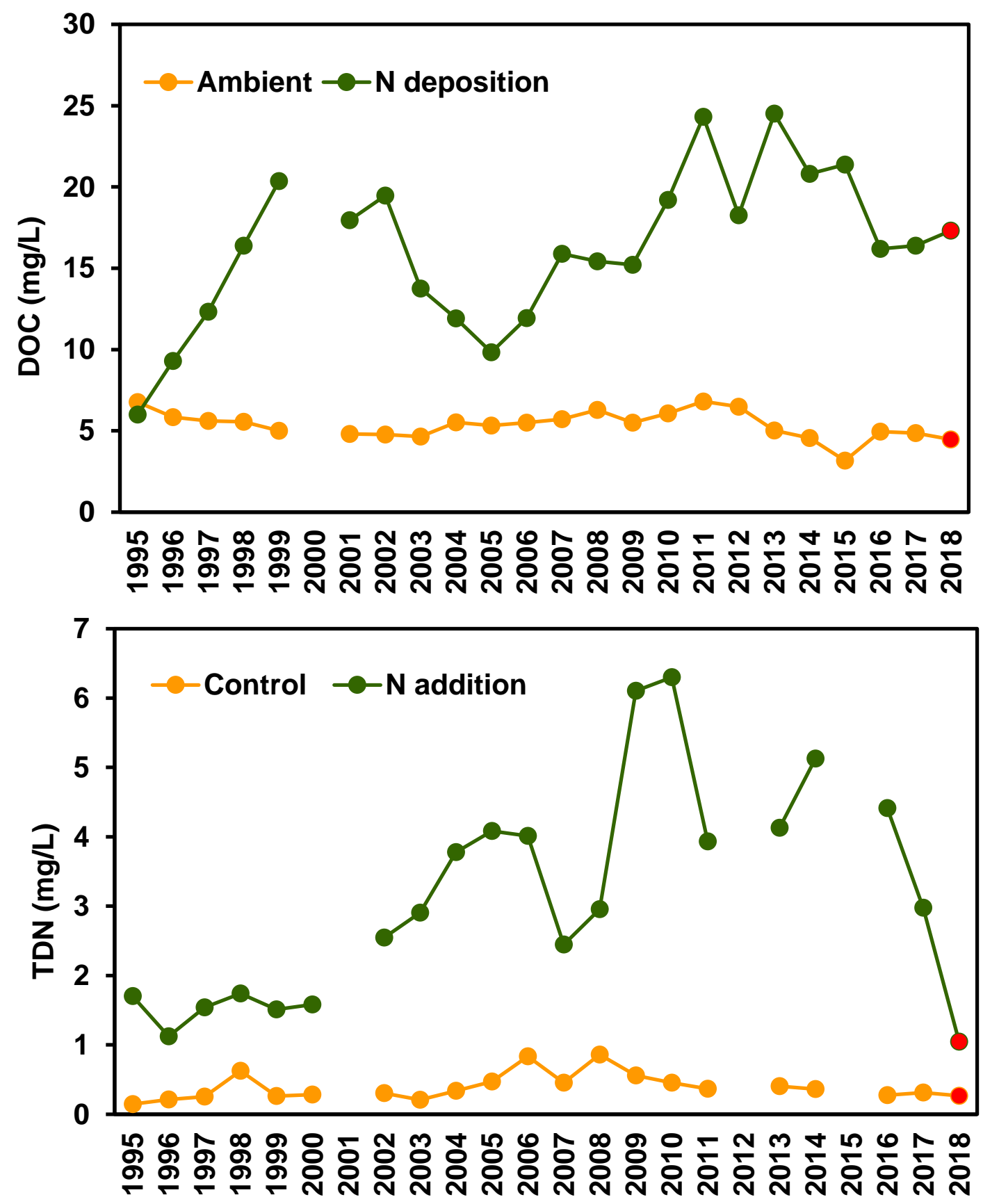

Figure 7. Soil solution dissolved organic C (DOC, upper plate) and total dissolved N (TDN, lower plate) concentrations for Site A, Michigan, for the control and $\mathrm{N}$ deposition treatments from 1994 to 2018. Experimental N deposition treatments were applied from 1994 to 2017. The red data points for 2018 indicate the first year of post-treatment data. 
Table 4. Single factor analysis of variance of the soil solution TDN (mg N L-1) and DOC (mg C L ${ }^{-1}$ ) from Site A in Michigan, 2018.

\begin{tabular}{ccccccc}
\hline Analyte & Source of Variation & SS & df & MS & F & $\boldsymbol{P}$-value \\
\hline TDN & Treatment & 0.913 & 1 & 0.913 & 45.6 & 0.003 \\
& Error & 0.0803 & 4 & 0.020 & & \\
& Total & 0.993 & 5 & & & \\
& & & & & & \\
DOC & Treatment & 248.22 & 1 & 248.22 & 12.51 & 0.024 \\
& Error & 79.351 & 4 & 19.83 & & \\
& Total & 327.57 & 5 & & & \\
& & & & & & \\
\end{tabular}

\section{Discussion}

Since the ecosystem is likely still $\mathrm{N}$ saturated from 24 years of $3 \mathrm{~g} \mathrm{NO}_{3}^{-}-\mathrm{N} \mathrm{m}^{-2} \mathrm{y}^{-1}$ of $\mathrm{N}$ being deposited on the site, the leaf litter was expected to still have a higher $\mathrm{N}$ concentration. The effect of the $\mathrm{N}$ deposition treatment on leaf litter concentrations was greater during the deposition study ( $21 \%$ increase over the control) than during the recovery study (10\% more than the control in 2018) (Figure 4 and 5). This change may suggest that future years will experience further decreases in litter $\mathrm{N}$ in the former $\mathrm{N}$ deposition treatment.

To understand why $\mathrm{C}$ concentrations in the leaf litter are elevated is more complex and not fully understood. One possibility is that the shifts in nutrient ( $\mathrm{N}$ and $\mathrm{C}$ ) concentrations are 
both related to the compounds being retained in the leaf litter rather than resorbed. Tree leaf biomolecules can include lipids, carbohydrates, protein, and nucleic acids, all of which differ in their typical $\mathrm{C}$ and $\mathrm{N}$ concentration. When the tree prepares to resorb nutrients prior to dropping its leaves before winter, $\mathrm{N}$ is a priority. However, in locations with greater soil $\mathrm{N}$ availability, a lower proportion of $\mathrm{N}$ is typically resorbed, with more $\mathrm{N}$ left in the senescing leaves. This was the case for the $\mathrm{N}$ deposition treatment - less $\mathrm{N}$ was resorbed from the leaves, leaving higher $\mathrm{N}$ concentrations in leaf litter. Two of the more likely $\mathrm{N}$ rich compounds "left behind" in the leaves to create this effect are residues of chlorophyll and proteins. These have a higher percent C (74\% for chlorophyll, 54\% for protein) than the bulk leaf litter of the control treatments ( $47 \% \mathrm{C}$ ). This suggests a coupling effect where factors causing excess $\mathrm{N}$ in the leaf litter may also induce leaf litter $\mathrm{C}$ to go up slightly.

Soil solution TDN remained elevated in the former $\mathrm{N}$ deposition treatment at Site A in 2018, but at a lower level than during the treatment period. One can estimate the flux of $\mathrm{N}$ loss in soil solution by multiplying the TDN concentration by soil water recharge. The soil water recharge at Site A is typically 40 to $50 \mathrm{~cm}$ annually (Pregitzer et al. 2004), which would lead to an increase in TDN leaching export of about $0.4 \mathrm{~g} \mathrm{~N} \mathrm{~m}^{-2} \mathrm{y}^{-1}$ in the former $\mathrm{N}$ deposition treatment versus the control for the very wet year that occurred in 2018. Annual ambient $\mathrm{N}$ deposition inputs to Site A are 0.4 to $0.5 \mathrm{~g} \mathrm{~N} \mathrm{~m}^{-2}$ y (Table 2), which are approximately equal to soil solution TDN leaching losses in 2018. This suggests that at Site A the system had not yet recovered, and in fact remained $\mathrm{N}$ saturated, with soil solution $\mathrm{N}$ losses essentially equal to deposition $\mathrm{N}$ inputs. 
The findings of this report suggest that even though the $\mathrm{N}$ deposition treatment had stopped, a state of $\mathrm{N}$ saturation persisted in 2018 , continuing to cause many of the responses associated with elevated $\mathrm{N}$ deposition. In the former $\mathrm{NO}_{3}$ deposition treatment at Site $\mathrm{A}, \mathrm{a}$ significant decline occurred in 2018 for soil solution TDN when compared to the concentrations measured during the $\mathrm{N}$ deposition study. The change is equivalent to the absence of artificial inputs of $3 \mathrm{~g} \mathrm{NO}_{3}{ }^{-}-\mathrm{N} \mathrm{m}^{-2} \mathrm{y}^{-1}$, due to the fact that $\mathrm{N}$ is no longer being experimentally deposited on the sites, ultimately affecting the overall input flux. Although the fluxes have changed the sites remain $\mathrm{N}$ saturated and are being sustained solely by the natural inputs $\mathrm{N}$ to the site itself (wet and dry atmospheric $\mathrm{N}$ deposition) and internal ecosystem cycling of litter N. Future study will draw a clearer picture of whether this N saturated system will be able to sustain this state and for how long.

Soil solution DOC export in the former $\mathrm{N}$ deposition treatment remained as elevated in 2018 as it was during the deposition treatment period from 1994 to 2017. This suggests the alteration of microbial function by excess $\mathrm{N}$ that led to reduced litter decomposition and creation of elevated DOC continues to occur. If the nitrogen availability in the system returns to normal levels (recovers), the microbial processes may also recover. However, it would be expected that microbial communities returning back to normal levels would require more time to rebound than $\mathrm{N}$ leaching in the system. It is evident that the DOC recovery depends greatly on how much $\mathrm{N}$ is in the system. This relationship is apparent in the data, TDN has quickly declined (due to the change in $\mathrm{N}$ inputs) but still indicates an $\mathrm{N}$ saturated system, whereas the DOC has stayed relatively the same. 
At the time of this study in 2018 , Site B was affected by a heavy forest tent caterpillar (Malacosoma disstria) infestation, which may have slightly affected leaf litter $\mathrm{N}$ concentrations for that site. Although such environmental occurrences are not strongly evident within the data (Figure 4, upper plate, Site B), it is important to assess how such disturbances and environmental factors play into the study. With speculation, one could suggest that the chewing effect by the caterpillars will promote a premature release of more nutrient rich leaf fragments to enter the litter traps earlier into the season. Whereas leaves that fall normally at the end of the season have more nutrients removed by the tree resorbing the nutrients before the leaf drops. Although small, the nutrient rich leaf fragments can ultimately increase the average $\mathrm{N}$ concentration in litter fall composited for the entire growing season. It is also possible that effects of the tent caterpillar may be more apparent in the following year's data, due to alteration of resorption and subsequent reallocation to the next year's foliage. With more time, a clearer picture of the factors that drive $\mathrm{N}$ recovery and the time it takes for a system to fully recover will become more apparent.

\section{Conclusion}

The presence of $\mathrm{N}$ on the landscape, caused by anthropogenic activities, has increased from $\sim 12 \mathrm{~kg} \mathrm{~N}$ capita $^{-1} \mathrm{yr}^{-1}$ to $\sim 30 \mathrm{~kg} \mathrm{~N}_{\text {capita }}{ }^{-1} \mathrm{yr}^{-1}$ over the period 1850-2010 (Galloway et al. 2004). This 2018 study is used to evaluate the recovery effects following a simulated chronic $\mathrm{NO}_{3}$ deposition experiment from 1994 and 2017. Due to effectiveness of NOx emissions regulations, $\mathrm{N}$ deposition levels are predicted to decrease in portions of the United States and Europe, therefore an understanding of ecosystem behavior and response is vital for regions where shifts and potential for a decline in $\mathrm{N}$ deposition may occur. This 
type of recovery in $\mathrm{N}$ saturated systems is going to have increasing importance for ecosystem modeling globally and for future decision making in Eastern Europe and Asia, as such regions are beginning to experience extreme $\mathrm{N}$ deposition that in certain areas is much higher than the past peak levels in the USA (Lu et al. 2016a). The results of this study can help scientists and policy makers in these areas deduce whether the $\mathrm{N}$-saturation effects are reversible and, if so, at what rate we can expect ecosystems to recover. This enables informed decisions regarding the shifting of resources to limit $\mathrm{N}$ emissions and further reduce atmospheric $\mathrm{N}$ deposition. 


\section{References}

Aber, J.D., K.J. Nadelhoffer, P. Steudler, and J.M. Melillo. 1989. Nitrogen saturation in northern forest ecosystems. BioScience 39:378-386.

Aber, J.D., W. McDowell, K. Nadelhoffer, A. Magill, G. Berntson, M. Kamakea, S. McNulty, W. Currie, L. Rustand, and I. Fernandez. 1998. Nitrogen saturation in temperate forest ecosystems: hypotheses revisited. BioScience 48:921-934.

Braun, E.L. 1950. Deciduous forests of eastern North America. Macmillan Publishing Co, Inc. 596 p.

Burton, A.J., K.S. Pregitzer, J.N. Crawford, G.P. Zogg, and D.R. Zak. 2004. Simulated chronic NO3- addition reduces soil respiration in northern hardwood forests. Global Change Biology 10:1080-1091.

Burton, A.J., J.C. Jarvey, M.P, Jarvi, D.R. Zak, and K.S. Pregitzer. 2012. Chronic N deposition alters root respiration-tissue $\mathrm{N}$ relationship in northern hardwood forests. Global Change Biology 18:258-266.

CASTNET, Clean Air Status and Trends Network. Total deposition of nitrogen 1517, USEPA 02/19/19. https//www3.epa.gov/castnet/maps/tdep/1517/n_tw-1517.png, accessed 28 May, 2019.

Du, E. W. de Vries, J.N. Galloway, X. Hu, and J. Fang. 2014. Changes in wet nitrogen deposition in the United States between 1985 and 2012. Environmental Research Letters 9:095004.

Frey, S.D., S. Ollinger, K. Nadelhoffer, R. Bowden, E. Brzostek, A. Burton, B.A. Caldwell, S. Crow, C.L. Goodale, A.S. Grandy, A. Finzi, M.G. Kramer, K. Lajtha, J. LeMoine, M. Martin, W.H. McDowell, R. Minocha, J.J. Sadowsky, P.H. Templer, and K. Wickings. 2014. Chronic nitrogen additions suppress decomposition and sequester soil carbon in temperate forests. Biogeochemistry 121:305-316.

Galloway, J.N., W. Winiwarter, A. Leip, A.M. Leach, A. Bleeker and J.W. Erisman. 2014. Nitrogen footprints: past, present and future. Environmental Research Letters 9:115003. 
Ibanez, I., D. Zak, A.J. Burton, K. Pregitzer. 2016. Chronic nitrogen deposition alters allometric relationships in a dominant tree species: Implications for woody biomass production and ecosystem carbon storage. Ecological Applications 26:913-925.

Lu, X., H. Jiang, X. Zhang, J. Liu and J. Jin. 2016a. Estimating 40 years of nitrogen deposition in global biomes using the SCIAMACHY $\mathrm{NO}_{2}$ column. International Journal of Remote Sensing 37:4964-4978.

Lu, X., H. Jiang, J. Liu, X. Zhang, J. Jin, Q. Zhu, Z. Zhang and C. Peng. 2016b. Simulated effects of nitrogen saturation on the global carbon budget using the IBIS model. Scientific Reports 6:39173.

Lyons, B. 2012. Nitrogen Deposition Effects on Production and Decomposition of Coarse Woody Debris. MS Thesis, Michigan Technological University, Houghton, MI.

Magnani, F., M. Mencuccini, M. Borghetti, P. Berbigier, F. Berninger, S. Delzon, A. Grelle, P. Hari, P.G. Jarvis, P. Kolari, A.S. Kowalski, H. Lankreijer, B.E. Law, A. Lindroth, D. Loustau, G. Manca, J.B. Moncrieff, M. Rayment, V. Tedeschi, R. Valentini and J. Grace., 2007. The human footprint in the carbon cycle of temperate and boreal forests. Nature 477: 848-850.

Matejovic, I. 1993. Determination of Carbon, Hydrogen, and Nitrogen in Soils by Automated Elemental Analysis (Dry Combustion Method). Communications in Soil Science and Plant Analysis 24: 2213-2222.

Patterson, S.L., D.R. Zak., A.J. Burton, A.F. Talhelm, and K.S. Pregitzer. 2012. Simulated $\mathrm{N}$ deposition negatively impacts sugar maple regeneration in a northern hardwood ecosystem. Journal of Applied Ecology 49:155-163

Pregitzer, K.S., D.R. Zak, A.J. Burton, J.A. Ashby, and N.W. MacDonald. 2004. Chronic nitrate additions dramatically increase the export of carbon and nitrogen from northern hardwood ecosystems. Biogeochemistry 68:179-197.

Pregitzer, K.S., A.J. Burton, D.R. Zak and A.F. Talhelm. 2008. Simulated chronic N deposition increases carbon storage in northern temperate forests. Global Change Biology 14:142-153.

Rogora, M., L. Colombo, A. Marchetto, R. Mosello, and S. Steingruber. 2016. Temporal 
and spatial patterns in the chemistry of wet deposition in Southern Alps.

Atmospheric Environment 146:44-54.

Talhelm, A.F., A.J. Burton, K.S. Pregitzer, and M.A. Campione. 2013. Chronic nitrogen deposition reduces the abundance of dominant forest understory and groundcover species. Forest Ecology and Management 293:39-48.

Talhelm, A.F., K.S. Pregitzer, and A.J. Burton. 2011. No evidence that chronic nitrogen additions increase photosynthesis in mature sugar maple forests. Ecological Applications 21:2413-2424.

van Diepen, L.T.A., E.A. Lilleskov, K.S. Pregitzer, and R.M. Miller. Simulated nitrogen deposition causes a decline of intra-and extraradical abundance of arbuscular mycorrhizal fungi and changes in microbial community structure in northern hardwood forests. Ecosystems 13: 683-695.

Whittinghill, K.A., W.S. Currie, D.R. Zak, A.J. Burton, and K.S. Pregitzer. 2012. Anthropogenic $\mathrm{N}$ deposition increases soil $\mathrm{C}$ storage by decreasing the extent of litter decay: analysis of field observations with a biogeochemical model. Ecosystems doi: 10.1007/s10021-012-9521-7.

Zak, D.R., W.E. Holmes, A.J. Burton, K.S. Pregitzer and A.F. Talhelm. 2008. Atmospheric $\mathrm{NO}_{3}{ }^{-}$deposition increases soil organic matter by slowing decomposition in a northern hardwood ecosystem. Ecological Applications 18: 2016-2027. 